\title{
Entrepreneurship Education Impact on Self-employment Intention: Case of University Students in Ethiopia
}

\author{
Belay Kinati Debelo ${ }^{1, *}$, B. Mohan Venkata Ram ${ }^{2}$ \\ ${ }^{1}$ Marketing Department, Wollega University, Oromia, Ethiopia \\ ${ }^{2}$ Department of Commerce \& Management Studies, Andhra University, Visakhapatnam, India \\ Email address: \\ belayknt@gmail.com (B. K. Debelo),bmohanvram@gmail.com (B. M. V. Ram) \\ ${ }^{*}$ Corresponding author
}

\section{To cite this article:}

Belay Kinati Debelo, B. Mohan Venkata Ram. Entrepreneurship Education Impact on Self-employment Intention: Case of University Students in Ethiopia. International Journal of Economics, Finance and Management Sciences. Vol. 9, No. 5, 2021, pp. $183-192$. doi: $10.11648 /$ j.ijefm.20210905.13

Received: April 21, 2021; Accepted: September 17, 2021; Published: October 5, 2021

\begin{abstract}
Entrepreneurship is learned as a course in most universities or colleges across the globe, and Ethiopia is not an exceptional. It is taught to provide students an entrepreneurial skills and knowledge so that they could identify business opportunities, find and gather resources and set up a business to mention a few. However, the impact entrepreneurship education has on university students' self-employment intention been unclear. The study targeted 2016 graduating class students of Mettu University and Jimma University, Faculty/College of Engineering and Technology, and Business and Economics. To address the issue, primary data were collected from both entrepreneurship students (students who had taken entrepreneurship course- 316 students) and non-entrepreneurship students (students who did not yet take the course-185 students). Having collected data from 501 students, comparison between entrepreneurship and non-entrepreneurship students concerning attitudes towards self-employment, perceived behavior control and self-employment intention were done. In addition, using multiple regressions, impact of attitude, subjective norms and perceived behavior control on self-employment intention also done. Results indicated that participating in an entrepreneurship course or education influence university students' attitude towards self-employment and self-employment intention. But, it has failed to have an effect on the students' entrepreneurial skill aspects, indicating that skill components of the entrepreneurship course need to be emphasized in Ethiopian higher learning institutions in order to enable students transform their business idea into reality. Thus, entrepreneurship curriculum needs to be reviewed, and the course should be taught by professionals, university-industry linkage initiatives should be given greater attention and experienced entrepreneurs should be invited to class or workshop in order to impart their experiences to students.
\end{abstract}

Keywords: Impact, Entrepreneurship Education, University, Self-Employment Intention, Ethiopia

\section{Introduction}

\subsection{Background of the Study}

Entrepreneurship is a hot issue for leaders across the globe [1]. Austrian-born American Management guru, Peter Drucker, described it as a discipline and is learned like any other disciplines [2]. In this context, entrepreneurship education can described as an instruction for opportunity recognition, assessing and acquiring resources and initiating a business venture [3]. According to Kissi Ernest et al. [4], it aims to impart students the attitude, skills and information that are needed later on in working life. In other words, the entrepreneurial education raises learners' awareness of self-employment as a career option, via affecting their attitude towards entrepreneurship, promoting the development of personal qualities and providing technical and business skills that are needed in order to start and run a new business.

From past studies, there is dispute among scholars regarding the correlation between entrepreneurship education and self-employment intention. Some scholars, targeting tertiary school students, agreed that the two parameters have a positive relationship [5]. For instance, Gibcus et al. [6] in 
nine European countries; Ekpoh and Edet [1] in Nigeria; Alhaji [7] in Ghana; Maisaroh et al. [8] in Indonesia had confirmed the presence of direct relationship between entrepreneurship training and propensity for selfemployment. Similarly, study conducted by Lee et al. (2005) in South Korea and the US as cited by Zwan et al. [9] reinforced the above-mentioned finding. To measure entrepreneurship education, the researchers had used the theory of planned behavior (TPB). TPB states that a person's behavior is determined by the behavior intention, which is in turn the function of attitude towards behavior, subjective norm and perceived behavior control.

On the contrary, there are scholars who disagreed on the direct relationship between entrepreneurship education and self-employment intention. For example, Oosterbeek et al. (2010), in Hussain [10] concluded that the negative impact of entrepreneurship education on entrepreneurship intentions. In the study, it was also reported that entrepreneurship education impact on entrepreneurial skills/ traits was significantly zero or negative. A study by Graevenitz, Harhoff, and Weber (2010), also, found the effect of entrepreneurship education on entrepreneurial intentions decreased in certain extent, even though the entrepreneurship course has significantly positive impact on students' entrepreneurial skills [10].

To the end, according to a World Bank report of July 2015, global awareness about entrepreneurship education and its impact is still at a minimum [11]. To be specific, in Ethiopia, entrepreneurship subject has been taught neither by entrepreneurship specialized educators nor entrepreneurs. In addition, few empirical studies are there regarding entrepreneurship education impact on students' selfemployment intention [12].

\subsection{Objectives of the Study}

The broad objective of the study was to explain the impact of entrepreneurship education on university students' selfemployment intention in south-west Oromia, Ethiopia. The specific objectives were:

(1) To explain the effect of entrepreneurship education on university students' attitude towards selfemployment,

(2) To clarify the effect of entrepreneurship education on university students' perceived behavior control.

(3) To explain the effect of entrepreneurship education on university students' self-employment intention.

(4) To explain the impact of subjective norms, attitude towards self-employment and perceived behavior control on self-employment intention.

\section{Related Literature Review}

Literature helps to share with readers the results of other studies that are closely related to the one being undertaken [16]. Thus, this section focused on reviewing literature for connecting entrepreneurship educations to self-employment intention.

\subsection{Participate in Entrepreneurship Training}

Entrepreneurship education aims to empower learner with skills that will enable him/her to engage in income giving business enterprise irrespective of his/her areas of specialization [34]. Kissi Ernest et al. [4] revealed that the aim of entrepreneurship education is to impart students the attitude, skills and information that are necessary later in your professional life, whether you work for someone else or as an independent entrepreneur. In this regard, those researchers summarized the levels of entrepreneurial education objectives as (i) raising learners' awareness of selfemployment as a career option, via affecting students' attitude; (ii) promoting the development of personal qualities that are relevant to entrepreneurship, such as risk taking and responsibility, and providing the technical and business skills that are needed in order to start and run a new business.

\subsection{Self-Employment Intention Theories}

A person's self-employment intention is the important variable to predict his or her self-employment behaviors. Although there is no universally accepted definition for selfemployment intentions, which is used interchangeably with entrepreneurial intention in this paper, the concept forwarded by Van Gelderen et al. [33] was used. Accordingly, selfemployment intention is the intention/plan to set up one's own business in the future.

To examine an individual's self-employment intention, several models have been used. However, Ajzen's [35] Theory of Planned Behavior (TPB) is the first and the most widely used. It focuses on attitude as the best predictor of intention and uses the attitude toward the act, social norms and perceived behavioral control to predict self-employment intention. The attitude towards the behavior (selfemployment) refers to the degree to which a person has a favorable or an unfavorable evaluation of business start-up. Perceived behavior control refers to the self-efficacy or ability of students to start business Ajzen [35] that is the student's faith in his/her ability to start and run a business. On the other hand, the subjective norms refer to the perceived social pressure to perform or not to perform the behavior (startup of some sort of business). Since, subjective norms, attitude towards self-employment and perceived behavior control influence self-employment intention; theory of planned behavior is appropriate in measuring selfemployment intention of undergraduate graduating class students and was employed.

\subsection{Entrepreneurship Training and Intention to Become Self-employed}

As it was exemplified in the background section of this paper, scholars took different side in relation to the impact of entrepreneurship education on self-employment intention. Some argued that there is a direct relationship between entrepreneurship education and self-employment intention, while others said there is no or negative (see background section). This depicts the presence of disagreement among 
researchers and the need to further conduct research. In addition, global awareness about entrepreneurship education and its impact is still at a minimum.

\subsection{Conceptual Framework and Hypothesis}

In order to develop a conceptual framework, the association between entrepreneurship education and theory of planned behavior which consisted attitude towards self-employment, perceived behavior control on self-employment intention as well as the influence of entrepreneurship education on attitude, perceived behavior control and self-employment intention was adapted from entrepreneurial intention model developed by Wu, S. \& Wu L. 2008 cited by Pretheeba [13].

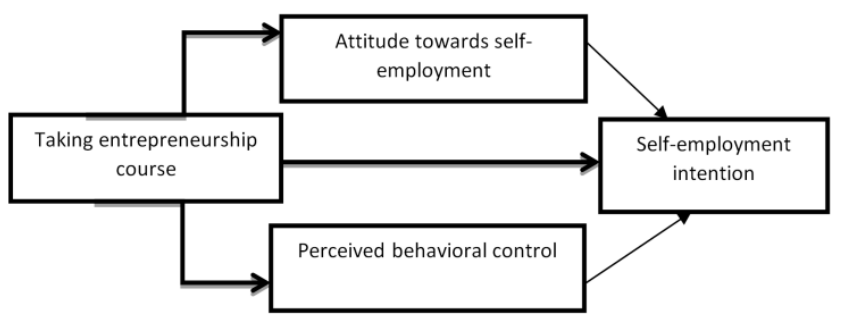

Figure 1. Entrepreneurship course and TPB.

Source: Adapted from Entrepreneurial intention model by Wu, S. \& Wu L. 2008 used by Pretheeba [13].

In figure 1, it was clearly indicated that if the knowledge transferred to students by means of entrepreneurship course focused on the development of students' skills and attitudes, it could in turn enable them to recognize opportunity, assess and acquire resources, and initiate a business venture. In this regard, taking Mettu University and Jimma University students as participants of the study, the contribution of entrepreneurship education in influencing these students' self-employment intention, attitude towards self-employment and perceived behavior control had been investigated. In line with the above illustration, the conceptual framework and the hypotheses were designed and derived as follows:

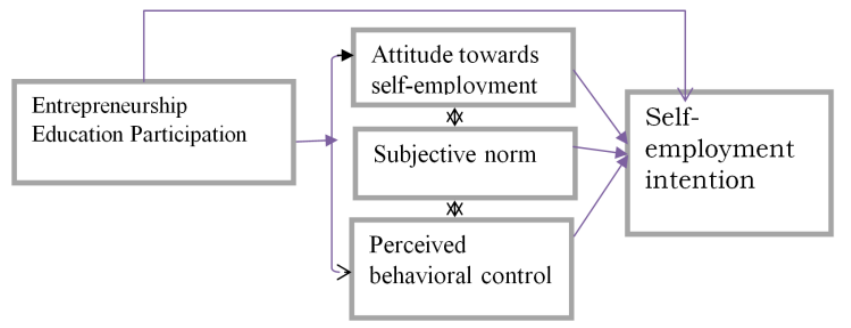

Source: Developed for the study, 2016.

Figure 2. Conceptual Framework.

\section{Hypotheses}

$\mathrm{H}_{1}$ : Attitude towards self-employment significantly influence students' self-employment intention.

$\mathrm{H}_{2}$ : Subjective norms towards self-employment significantly influence students' self-employment intention.

$\mathrm{H}_{3}$ : Perceived behavior control significantly influence students' self-employment intention.
$\mathrm{H}_{4}$ : There is a significant difference between students participated in entrepreneurship course and students not participated regarding attitude towards self-employment, perceived behavior control and self-employment intention.

\section{Materials and Methods}

\subsection{Research Design}

It is a blueprint for empirical research aimed at answering specific research questions or testing specific hypotheses [14]. Since, this paper aims at testing theory/hypothesis, positivist method particularly survey research is preferred.

\subsection{The Survey Design}

Survey research was preferred as it is the best means for measuring unobservable data, such as people's attitudes and belief; economical in terms of time, effort and cost [14] and individuals are used as a unit of analysis [15]. But it is subject to non-response bias and sampling bias [14] that was managed by data screening and random sampling technique respectively. In respect to the number of times data were collected, cross-sectional survey design was employed. Cross-sectional survey data is collected at one point at a time from the sample respondents [16].

\subsection{Data and Its Sources}

All studies require some form of data collection and entry [17] as the data allow researchers to describe phenomena, predict events, identify and quantify differences between conditions and establish the effectiveness of interventions. According to this, attitudinal, intentional and educational data were obtained from graduating class university students, entrepreneurship and enterprise development course instructors and faculty deans. Furthermore, secondary data sources have been used to enhance the quality and relevance of the data. The secondary data have already been collected by someone else and has already been passed through the statistical process [18]. The data were collected from journal articles, entrepreneurship books, research books, statistics books and websites.

\subsection{Sample Design and Its Process}

A sample design is the road map that serves as the basis for the selection of a survey sample [19]. It begins with a population of interest from which information is gathered and ends with sampling techniques employed to select the sample.

Population is the entire group of people that the researcher wishes to investigate, while a sample is a subset of the population [20]. Thus, the study population is the final-year undergraduate business, economics and engineering students of Jimma University and Mettu University from 2015 October to 2016 June. The total population was 3,010, among which 2004 students have taken the entrepreneurship course, while the remaining 1006 were not. Sampling unit are individuals that exist within the population of interest, 
whereas the sampling frame is a list of all the peoples from which the sample is selected [21]. In this paper, the sampling unit was business, economics and engineering students and the lists of them were obtained from corresponding faculty. When the size of the population is known and finite, the sample size is calculated using the formula:

$$
\mathrm{n}=\frac{Z^{2} \cdot P \cdot Q \cdot N}{e^{2} \cdot(N-1) \cdot+Z^{2} \cdot P \cdot Q}
$$

Source; Kothari [18]

Where

$n=$ sample size;

$N=$ population size;

$P=$ population proportion at which the sample size is maximized $(p=0.5)$;

$Q=$ equals $1-P(q=0.5)$;

$Z=$ the test statistic under the (1- $\alpha) \%$ significance level $(z=1.96)$;

$e=$ the tolerance $(5 \%=0.05)$.

Using the above given formula, the sample size was 341

Ozer 2004 stated that the formula is used to determine the minimum representative sample size of the survey [22]. In line to this, since 341 sample members were the minimum representative sample size and the larger the sample size the more accurate the findings [23], 615 students were considered. In the end, 407 study participants were selected from students who had taken the entrepreneurship course, while 208 sample elements were selected from students who did not yet take the course. Using purposive sampling technique, two universities: Jimma and Mettu were selected as it was feasible in terms of time and money costs. In addition, purposive sampling technique was employed to select Business and Economics College, and Engineering College students. Business and economics students were chosen as they come across entrepreneurship and business concepts in various courses. Considering engineering students are very imperative as what they learn is physically visible practical task and have great contribution to economic growth and development. Thirdly, the entrepreneurship course itself was mostly given to the aforesaid two colleges and there was less research in relation to this topic in the colleges. Simple random sampling was selected, as with randomization a representative sample from a population provides the ability to generalize to a population and reduces sample bias [16]. In this study, in order to collect data, the semistructured questionnaires were randomly distributed to most students in the classroom using a random technique.

\subsection{Data Collection Methods}

Based upon ways data are collected, survey instruments can be categorized into questionnaire survey and interview survey [14]. In this study, semi-structured questionnaire survey and personal interview survey were employed. Entrepreneurial intention questionnaire (EIQ) survey instrument was used for data collection. Liñán and Chen (2009) designed and tested EIQ survey instrument [15]. Many scholarly researches argued that the entrepreneurial intention questionnaire was designed for the theory of planned behavior as it is applied to entrepreneurship [15]. In this research study, the sample question items were (i) will start own business after graduation in the future [24] in order to determine self-employment intention (ii) consider selfemployment as a career [25] to evaluate perceived attitude towards self-employment (iii) have the skills and capabilities required to succeed as an entrepreneur and have control over resources to start my business [26] in order to evaluate perceived behavior control and, (iv) believe my family thinks I should pursue a career by creating my own business [26] to measure perceived subjective norms towards selfemployment. In order to evaluate the items on the instrument, a five-point Likert scale and categorical scales were used. In the five - point Likert scale, $1=$ strongly disagree, while $5=$ strongly agree. Similarly, $1=$ yes while $2=$ no response. The instrument covers data on attitudinal items, behavioral items, educational items and social pressure items.

\subsection{Instruments Validity and Reliability}

Reliability is the ability of an instrument to produce consistent measurements. The instrument is considered to be reliable when researchers collect the same set of information more than once using the same instrument and get the same /similar/ results under the same or similar conditions [23]. In social science, various factors such as the wording of questions, a change in a respondent's mood when responding to questions or statements and so on affects the reliability of a research tool [23].

There are quite a good number of different aspects pertaining to reliability. One is concerned with the scale's internal consistency, which indicates the degree to which the items that make up the scale 'hang together'. In order to test internal consistency reliability of Likert type items, Cronbach's coefficient alpha is useful. Alpha is based on the average correlation of each item in the scale with every other item. Hence, Cronbach's (1994) alpha coefficient test was used to test the reliability of the instrument [27] (Oyugi, 2015) wherein the alpha coefficient $(\alpha)$ has a range from 0 to 1 , where the highest alpha coefficient indicates a high level of reliability [20]. Accordingly, if the result of Cronbach $(\alpha)$ is less than 0.60 , it is considered to be poor. If the result of Cronbach $(\alpha)$ is from 0.60 to 0.79 , it is considered to be acceptable and if the result of Cronbach $(\alpha)$ is over 0.80 , it is considered to be good. If the result of Cronbach's alpha coefficient $(\alpha)$ is over 0.90 , it is considered to be excellent [20].

The questionnaire was subject to validity and reliability test for the purpose of data quality control. The validity test would be carried out in the first place using factor analysis and then followed by reliability test which was checked out with the help of Cronbach alpha.

Factor Analysis

In this paper, convergent validity and discriminant validity have been performed for elements in the theory of planned behavior and accompanied by all elements in entrepreneurship training. Validity indicates the extent to which a measure adequately represents the underlying construct that it is supposed to measure. 
Accordingly convergent validity shows the closeness with which a measure relates to (or converges on) the construct that it is supposed to measure, while discriminant validity represents the degree to which a measure does not measure (or discriminates from) other constructs that it is not supposed to measure. Convergent validity and discriminant validity are evaluated together for a set of related constructs. While convergent validity can be established by comparing the observed values of an indicator of a construct with that of other indicators of the same construct and demonstrating similarity (or high correlation) between the values of these indicators, discriminant validity is established by demonstrating that indicators of one construct are dissimilar from (IE, have low correlation with) other constructs [14].

For adequate convergent validity, elements belonging to a common construct should have factor loads of 0.60 or more on a single factor (called loadings of the same factor), while for discriminant validity, these elements should have factorized loadings of 0.30 or less on all other factors (crossfactor loadings) [14].

Table 1. Reliability test results for the various measures in control group.

\begin{tabular}{llll}
\hline Measures & N of Items & Cronbach's Alpha & Acceptable Cronbach Alpha \\
\hline Self-employment intention & 3 & .666 & Acceptable \\
Attitudes towards self-employment & 2 & .625 & Acceptable \\
Perceived behavior control & 3 & .706 & Acceptable \\
Perceived social norm & 3 & .809 & Good \\
Average & 11 & .702 & Acceptable \\
\hline
\end{tabular}

Source: survey 2016 using SPSS 20.

Table 1 indicates the internal consistency reliability of items used to measure TPB elements. Accordingly, to measure self-employment intention, four statements, namely; 'I will make every effort to start and run my own business; I will start my own business after graduation; I will work together with good partners to start a new business and I will start my own business if financial support is available' were employed. However, for the corrected item-total correlation values shown in the item-total statistics table gives us an indication of the degree to which each item correlates with the total score. In line with this, low values (i.e. Less than 0.3 ) indicate here that the object measures something other than the scale as a whole. If the scale's overall Cronbach alpha is less than 0.7 removing items with low item-total correlations are needed to be done [28]. As a result, the question item 'I will start my own business if financial support is available wherein Corrected Item-Total Correlation is low (i.e. 0.237) was removed from among the items used to measure self-employment intention.

In a similar manner, to measure attitude towards selfemployment, three statements such as 'I prefer to be selfemployed than a large firm employee; I prefer to establish a new company than to be manager of existing one and I consider self-employment as career' were employed. Nevertheless, since the overall Cronbach alpha is less than 0.7 and the research instrument which says 'I prefer to establish new company than to be manager of existing one' had a Corrected Item-Total Correlation of 0.284 , it was removed from measuring attitude towards self-employment for students who did not yet take entrepreneurship course.

Hence, to measure attitude towards self-employment the remained two question items would be utilized. Furthermore, respects to perceived behavior control, four statements were considered. These are (i) I am confident that if I start my own business, the chances of success would be very high (i.e. Perceived self-efficacy); (ii) I know the necessary practical details to start a firm; (iii) I have control over necessary resources to start my own business and (iv) I have the skills and capabilities required to succeed as an entrepreneur.

However, the low overall Cronbach alpha has led to investigate, question item(s) which is/are not correlated with the overall factor. Accordingly, the question item stated as ' $I$ am confident that if I start my own business, the chances of success would be very high' was removed for nonentrepreneurship students. The reason was its Corrected Item-Total Correlation in the item-total statistics are low (i.e. 0.161). Consequently, only the three remaining items have been employed for further analysis.

In the end, from table 1, all sections passed the reliability tests. The average Cronbach's alpha was 0.702, which reaffirms that each section was reliable in as far as a measure of entrepreneurship intention was concerned. But, in order to compare the self-employment intention between entrepreneurship students and non-entrepreneurship students, the researchers have used constructs that were commonly reliable for both groups. The next reliability test would be carried out for entrepreneurship group [students with training in entrepreneurship].

Table 2. Reliability test results for the various measures in Entrepreneurship group.

\begin{tabular}{llll}
\hline Measures & N of Items & Cronbach's Alpha & Acceptable Cronbach alpha \\
\hline Self-employment intention & 4 & .841 & Good \\
Attitude towards self-employment & 3 & .611 & Acceptable \\
Perceived behavior control & 4 & .732 & Acceptable \\
Perceived social norm towards self-employment & 3 & .785 & Acceptable \\
Average & 32 & .742 & Acceptable \\
\hline
\end{tabular}

Source: Survey 2016 using SPSS 20. 
In respect of table 2, all sections passed the reliability tests. The average Cronbach's alpha was .742, which reaffirms that each section was reliable in as far as a measure of entrepreneurship was concerned.

\section{Results and Discussions}

In order to evaluate effectiveness of entrepreneurship education in influencing students' self-employment intention, attitude and behavior, data were collected from 508 students.

\subsection{Participants' Profile}

The student respondents whose characteristics were explained below had been drawn from both Jimma University and Mettu University.

\subsubsection{Gender}

The descriptive information on gender of respondents was summarized as in figure 3 below.

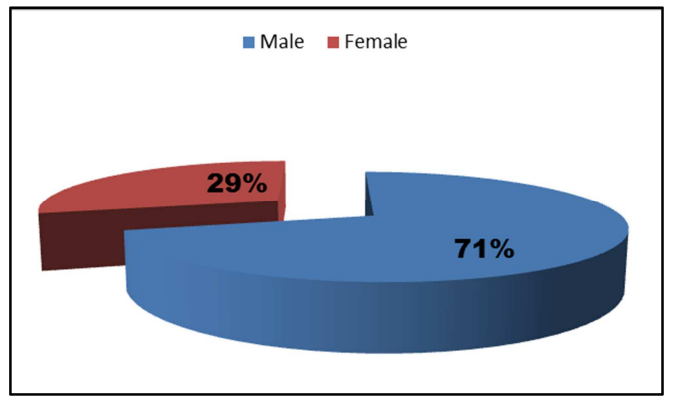

Source: Survey 2016 using SPSS 20.

Figure 3. Gender of Student Respondents.

The chart shows most student respondents were male. It indicates there are a higher number of males than girls in higher learning institutions partly due to academic dismissal. This depicts the need to enhance female students' active participation concerning academic affairs from the time they have joined the university to graduation.

\subsubsection{Age}

The age bracket frequency distribution of student respondents and its respective percentage were indicated as in figure 4 below.

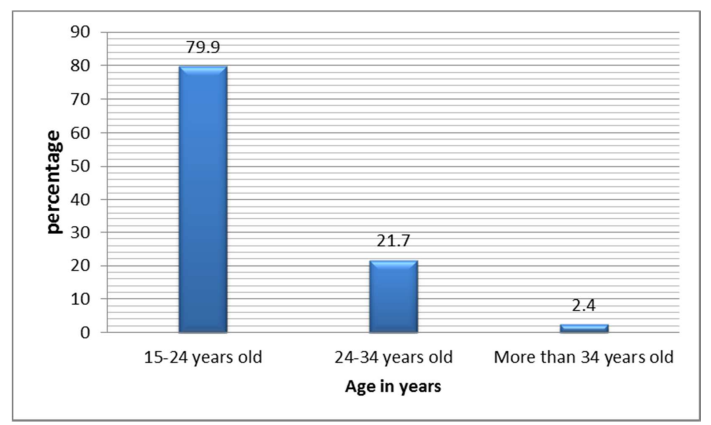

Source: Survey 2016 using SPSS 20.

Figure 4. Respondents'Age in Years.
Figure 4 revealed that 75.9 percent of the student respondents were found between 15 to 24 years age. This age interval is the age range of most university students in Ethiopian higher learning institutions (HLI). Besides, Global Entrepreneurship Monitor confirmed that it is an age interval for someone to be an entrepreneur as individuals of this age range has the capability to identify opportunities and willing to bear the risk of venture creation. Thus, these students get support to create and run businesses.

\subsubsection{Jobs Intention}

Students' graduation year is very critical as they go for either wage working or establishing their own business. They also work for wages and establishes business or continue education in parallel. Thus, the subsequent analysis hub on all study participants' job intention after completion of their higher education program in which they have three alternatives to choose from; job creation, working for another organization and others. The results were presented as in figure 5 below.

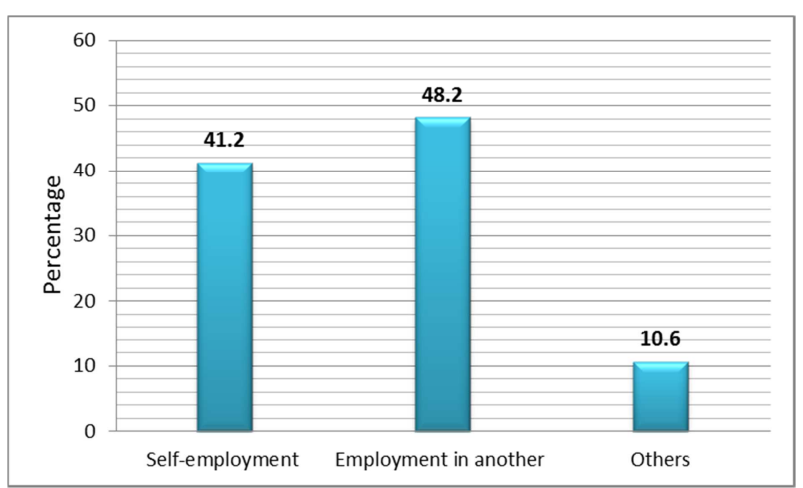

Source: Survey 2016 using SPSS 20.

Figure 5. Jobs Intention after graduation.

As it has shown in figure 5, 241 (48.2 per cent) of the students have preferred working for another company while 206 (41.2 per cent) of them have planned to initiate their own business after they graduated. Only 10.6 percent of the student respondents have an intention to do parallel works such as working for another company and starting a part-time business or continuing education. The result implies most students have no self-employment intention. This finding was supported by past studies conducted in Dire Dewa University, Ethiopia, by Atnafu [29] in which 77 per cent of sample student respondents have no entrepreneurial intentions. But, the self-employment intention is by far better when compared to previous studies if it would become actualized.

\subsection{Entrepreneurship and Non-entrepreneurship Students on Attitudes, Behavior Control and Intention}

Independent-samples t-test was deployed to conduct a comparison between entrepreneurship and nonentrepreneurship students regarding attitude towards selfemployment (ATSE), perceived behavior control (PBC) and 
self-employment intention (SEI). Since effect size statistics provide us an indication of the magnitude of the difference between groups, Eta Squared and Cohen's $d$., the most commonly used effect size statistics were employed. Eta squared can range from 0 to 1 and represents the proportion of variance in the ATSE, SEI and PBC (dependent) variables that is explained by the independent (participation on entrepreneurship course) variable [28]. Since eta squared is not available in SPSS, it has a formula as depicted below and was calculated manually.

The formula for eta squared is as follows:

$$
\text { Eta Squared }=\frac{t^{2}}{t^{2}+(N 1+N 2-2)}
$$

Where: t-refers to t- test value,

N1-sample size of the first group
N2- sample size of the second group

In line with this, Cohen (1988) in Pallant, [28] proposed the guidelines for interpreting eta squared value as indicated in table 3 below.

Table 3. Eta squared value and effect size.

\begin{tabular}{ll}
\hline Effect size & Eta Squared value \\
\hline Small effect & 0.01 \\
Moderate effect & 0.06 \\
Large effect & 0.14 \\
\hline
\end{tabular}

Hence, to contextually evaluate the effectiveness of entrepreneurship subject in influencing students' selfemployment intention, attitude towards self-employment and perceived behavior control the comparison results were presented in table 4 below.

Table 4. Comparison between entrepreneurship and non-entrepreneurship students on ATSE, PBC and SEI.

\begin{tabular}{|c|c|c|c|c|c|c|c|c|c|}
\hline \multirow[t]{2}{*}{ Variables } & \multicolumn{2}{|c|}{$\begin{array}{l}\text { Entrepreneurship } \\
\text { students }\end{array}$} & \multicolumn{2}{|c|}{$\begin{array}{l}\text { Non-entrepreneurship } \\
\text { students }\end{array}$} & \multicolumn{2}{|c|}{$\begin{array}{l}\text { Levine's Test for Equality of } \\
\text { Variances }\end{array}$} & \multicolumn{3}{|c|}{ T-test for Equality of Means } \\
\hline & Mean & SD & Mean & SD & $\mathbf{F}$ & Sig. & $\mathbf{t}$ & df & Sig.(2-tailed) \\
\hline SEI1 & 3.90 & 1.141 & 3.86 & 1.206 & 1.922 & .166 & .432 & 499 & .666 \\
\hline SEI2 & 3.90 & 1.243 & 3.76 & 1.250 & .128 & .720 & 1.168 & 499 & .243 \\
\hline SEI3 & 4.00 & 1.072 & 3.86 & 1.281 & 18.138 & .000 & 1.175 & 256.557 & .241 \\
\hline ATSE1 & 3.64 & 1.225 & 3.65 & 1.265 & 5.942 & .015 & -.147 & 348.397 & .883 \\
\hline ATSE3 & 3.88 & 1.137 & 3.78 & 1.145 & .038 & .845 & .890 & 499 & .374 \\
\hline PBC3 & 3.31 & 1.266 & 3.61 & 1.196 & 1.432 & .232 & -2.496 & 495 & .013 \\
\hline PBC4 & 3.45 & 1.265 & 3.73 & 1.184 & 2.304 & .130 & -2.361 & 493 & .019 \\
\hline
\end{tabular}

Source: Survey 2016 using SPSS.

To present and interpret results from the table 4, let us start with self-employment intention and then proceed to attitude towards self-employment and perceived behavior control.

In reference to self-employment intention, there is no statistically significant mean difference in scores for entrepreneurship students $(\mathrm{M}=3$. 90, $\mathrm{SD}=1.243)$ and nonentrepreneurship students, $\mathrm{M}=3$. 76, $\mathrm{SD}=1.250$; $\mathrm{t}(499)=$ $1.168, \mathrm{p}=.243$ (two-tailed) in intention to set up own business after graduation. The magnitude of the difference in the means (mean difference $=.140,95 \%$ CI: -0.095 to 0.374 ) was very small (eta squared $=0.003$ ). In a similar manner, an intention to make efforts to start own business and plan to work with partners to start business, did not statistically significantly influenced by participation on entrepreneurship education. Further, the results indicated that both entrepreneurship students and non-entrepreneurship students were agreed with the self-employment intention in which the mean agreement extent ranges from 3.76 to 4.00 (i.e. moderate to high mean value on a five point Likert scale basis) provided that entrepreneurship students have higher self-employment intention than non-entrepreneurship students. In short, students who have taken an entrepreneurship course have a higher self-employment intention than students who did not though the difference is not statistically significant.

In the same table, attitude towards self-employment was compared between the two groups. Two statements were used for comparing the attitude towards self-employment including 'prefer to be self-employed than a large firm employee (ATSE1)' and 'considers self-employment as a career (ATSE3)'. For both groups, there is a mean difference ranging from 3.64 to 3.88 (i.e. moderate to high mean value on five point Likert scale basis). The mean value of entrepreneurship group [e.g., ATSE3=3.88) is greater than the non-entrepreneurship group [e.g., ATSE3=3. 78]. Nevertheless, employing independent samples t-test, the attitude towards self-employment scores were compared for entrepreneurship students and non-entrepreneurship students; and the results indicated that there is no statistically significant mean difference in scores for entrepreneurship students $(\mathrm{M}=3.88, \mathrm{SD}=1.137)$ and non-entrepreneurship students, $\mathrm{M}=3$. 78, $\mathrm{SD}=1.145$; $\mathrm{t}(499)=.890, \mathrm{p}=.374$ (twotailed) in respects of considering self-employment as a career. The magnitude of the difference in the means (mean difference $=.097,95 \% \mathrm{CI}$ : -0.118 to -0.312 ) was very small (eta squared $=0$. 002). Therefore, in Ethiopian country context the entrepreneurship education has influenced the higher institutions students' attitude towards self-employment but the influence is statistically insignificant.

In the same table, perceived behavior control was also compared between entrepreneurship students and nonentrepreneurship students. In this regard, the agreement level of both groups of students on perceived behavior control elements is above average, ranging from 3.31 to 3.73 (i.e. 
low to moderate mean value of five point Likert scale basis). Students who did not yet take the entrepreneurship course have shown considerable perceived behavior control than students who have taken the course. The difference was statistically significant for two statements indicating entrepreneurship course failed to influence students'skills. In this view, the conversion of knowledge to action was overlooked in the entrepreneurship course teaching.

\subsection{Attitude, Subjective Norms and Perceived Behavior Control Impact on Self-Employment Intention}

Before deploying multiple regressions, multi-Co linearity problem that occurs when there are high inter correlations (i.e. Correlated at 0.50 and above) among attitude towards self-employment, perceived behavioral control and perceived subjective norms [30] was considered. As a multi-Co linearity meant two or more predictors contain much of the same information, highly correlated variables needs to be either aggregated into a composite variable or eliminated if the variable doesn't make a meaningful composite variable.

Moreover, the tolerance and the variance inflation factor (VIF) values in the Coefficients table were used for checking the existence of multi Co linearity. Tolerance and VIF give the same information (i.e. Tolerance=1/VIF) regarding the presence of multi Co linearity and if the Tolerance value is low $\left(<1-\mathrm{R}^{2}\right)$, then there is probably a problem with multi Co linearity. In this study, since adjusted $\mathrm{R}^{2}$ for intention and its predictors' is .305 and $1-\mathrm{R}^{2}$ is about .695 , then tolerances are not much lower and there is no multi Co linearity problem.

As multiple regressions use only the participants who have complete data (i.e. List wise exclusion) for all the variables [30] it involved data only from 312 participants.

In the correlation table, predictors of self-employment intention; perceived subjective norms, perceived behavior control and attitude towards self-employment were all significantly correlated with self-employment intention.

The model summary table shows that the multiple correlation coefficient (R), using all predictors simultaneously is $.558\left(\mathrm{R}^{2}=.312\right)$ and adjusted $\mathrm{R}^{2}$ is .305 , meaning that 30.5 per cent of the variance in selfemployment intention can be predicted from attitudes towards self-employment, subjective norms and perceived

\section{behavioral control combined.}

ANOVA table shows that $F=46.501$ and is significant. This indicates that the combination of predictors; attitude towards self-employment, perceived behavior control and subjective norms significantly predict self-employment intention. The other important table was the coefficient table. It indicated the standardized beta coefficients, which are interpreted similarly to correlation coefficient or factor weights. The $t$ value and the sign opposite each independent variable to indicate whether that variable is significantly contributing to the equation for predicting self-employment intention from the whole set of predictors.

In summary, multiple regressions were conducted to determine the best linear combination of attitude towards self-employment, perceived behavior control and perceived subjective norm predicting self-employment intention. The means, standard deviations, and inter correlations can be found in Table 4. These combinations of variables significantly predicted self-employment intention, F $(3,308)$ $=46.501, \mathrm{p}<.001$, with all three variables significantly contributing to the prediction. The beta weights, presented in Table 4, suggest that perceived behavior control contribute most to predicting self-employment intention and was followed by attitude towards self-employment. Perceived subjective norms also contributed to this prediction. This finding indicates less support comes from family, friends and perceived important person in encouraging plan to have one's own business as these people expects the graduated students to join government work after graduation. Because many people consider working in small and micro enterprises requires no wastage of time to hold a degree and they assume every person can do it even if the working condition is very traditional. Rather the access to resources and confidence in own skills and capability to start and run business encouraged students to have intended to start own business in the future. Furthermore, the positive attitude towards working for oneself encouraged students to have selfemployment intention. The adjusted R square value was .305 indicating $30.5 \%$ of the variance in self-employment intention was explained by the model representing large effect.

Table 5. Means, standard deviations, and inter correlations for self-employment intention and predictors.

\begin{tabular}{|c|c|c|c|c|c|}
\hline Variables & Mean & Std. dev & 1 & 2 & 3 \\
\hline $\begin{array}{l}\text { Self-employment intention } \\
\text { Predictor variables }\end{array}$ & 3.9119 & .98514 & $.409 * *$ & $.492 * *$ & $.341 * *$ \\
\hline Attitude towards self-employment & 3.7115 & .90023 & - & $.384 * *$ & $.194 * *$ \\
\hline Perceived behavioral control & 3.5729 & .88785 & & - & $.485 * *$ \\
\hline Perceived subjective norms & 3.4060 & 1.06876 & & & - \\
\hline
\end{tabular}

Source; survey 2016 using SPSS 20.

Based in table 5, the model equation was as follows:

$$
\begin{gathered}
\mathrm{SEI}=\beta 0+\beta 1 \mathrm{ATSE}+\beta 2 \mathrm{PBC}+\beta 3 \mathrm{SN}+\varepsilon \\
\mathrm{SEI}=1.151+.281 \mathrm{ATSE}+.366 \mathrm{PBC}+.120 \mathrm{SN}+\mathrm{e}
\end{gathered}
$$

From the model one can understand that, attitude towards self-employment, perceived behavioral control (PBC) and subjective norms positively and significantly affect selfemployment intention (SEI). This study results goes together 
with past study output done by Kolvereid [31] in Norway in which there were significant correlation among attitude towards self-employment, social norms and perceived behavioral control. In addition, the coefficient of $\mathrm{PBC}$ is higher than the two remained variables and its predicting power is high. It also assures the existence of nearly high correlation $(\mathrm{r}=.492)$ between PBC and SEI, that supports results obtained by Akanbi [32].

Table 6. Simultaneous multiple regression analysis summaries for ATSE, PBC and SN predicts SEI.

\begin{tabular}{llll}
\hline Variable & B (unstandardized coefficient beta) & SEB (standard error) & B (standardized coefficient beta) \\
\hline ATSE & .281 & .056 & .257 \\
PBC & .366 & .064 & .330 \\
SN & .120 & .050 & .130 \\
Constant & 1.151 & .242 & \\
$\mathrm{~N}=312$ & & & \\
\hline
\end{tabular}

Source; survey 2016 using SPSS 20.

\section{Conclusion and Recommendation}

\subsection{Conclusions}

There is the domination of male students in the higher educational institutions, especially in the final year, indicating the necessity of encouraging female students' participation since the dawn of their joining the university till getting graduation.

As hundreds of thousands of youths are attending higher learning institutions in the country, it is opportune time and place to encourage entrepreneurship development to bring in sustainable economic growth.

Most students need to work for wage by being employed in existing company keeping entrepreneurship as the second best alternative. This implies extra work is needed on mindset change towards entrepreneurship via creating awareness.

Entrepreneurship education increases the students' attitude towards self-employment and self-employment intention. But students' confidence in their ability to start and run a business as well as ways of obtaining resources that help to start and run business was not influenced by being taking entrepreneurship course. Hence, practical and skill based training is needed for students to increase their confidence in their ability.

\subsection{Recommendations}

Training on how to establish a new business (i.e. Business start-up) needs to be imparted for inspiring students to have their own business in the future after they finish their studies in collaboration with experienced entrepreneurs, competent trainers, experts in finance and researchers in entrepreneurship (for Educators).

The established university-industry linkage office in the university should be able to discuss with and persuade industries to take students in the internship form that help students to experience real work that in turn fills the skill gaps between what students possess and what the industries demand.

Universities should bring to the ground the initiatives of an entrepreneurship development in the country by opening entrepreneurship programs and centers that promote creativity and innovations among students and staff.

Since the labor supply to the labor market is greater than the labor demand in the labor market, the government media should and expected to work more on entrepreneurship promotion via creating awareness about the importance of entrepreneurship to society, economy and individual entrepreneurs.

\subsection{Limitations and Future Research Directions}

The time duration of data collection was one year and it's impossible to predict the actual behavior after graduation. Thus, the intention retention in relation to duration after entrepreneurship course/training attendance needs to be investigated to understand the trend of intention and its chance to be converted into practical, i.e. starting own business.

\section{Acknowledgements}

I would like to thank Mettu University for financing this study.

\section{References}

[1] Ekpoh U. and Edet A. (2011). Entrepreneurship Education and Career Intentions of Tertiary Education Students. International Education Studies.

[2] http://www.inc.com/encyclopedia/entrepreneurship.html

[3] Kåre Moberg, et al. (2014). How to assess and evaluate the influence of entrepreneurship education, The ASTEE projectAssessment Tools and Indicators for Entrepreneurship Education. Ireland: www.asteeproject.eu.

[4] Kissi Ernest et al., (2015). Towards Entreprenurial Learning Competencies: The perspective of Built Environment Students. Higher Education Studies, 21.

[5] Buba et al. (2015). The Effects of Entrepreneurship Education on University Students' Attitude and Entrepreneurial Intention. European Journal of Business and Management.

[6] Gibcus et al., (2012). Effects and impact of entrepreneurship programme in higher education: EIM Business \& Policy Research/European Commission. DG Enterprise and Industry. 
[7] Alhaji, A. (2015). Entrepreneurship education and its impact on self-employment intention and entrepreneurial selfefficacy. Humanities and Social Sciences, 57-63.

[8] Maisaroh, et al., (2013). Entrepreneurship Education and its Effect on Entrepreneurial Intention: Case Studies in the Faculty of Economics, State University of Jakarta. Proceedings of $23 \mathrm{rd}$ International Business Research Conference 18-20 November, (pp. 36-8). Melbourne, Australia.

[9] Zwan et al., (2013). Entrepreneurship education and selfemployment: the role of perceived barriers. Scientific Analysis of Entrepreneurship and SMEs.

[10] Hussain, A. (2015). Impact of Entrepreneurial Education on Entrepreneurial Intentions of Pakistani Students. Journal of Entrepreneurship and Business Innovation.

[11] http://www.worldbank.org/en/topic/education/publication/entr epreneurship-education-and-training-programs-around-theworld-dimensions-for-success

[12] Mudde, et al. (2015). Towards More Entrepreneurial Universities in Ethiopia, Policy Brief. Addis Ababa: internationalizing education.

[13] Pretheeba, P. (2014). Predicting Entrepreneurial Intention among Business and Engineering Students in Sri Lanka. Ruhuna Journal of Management and Finance.

[14] Bhattacherjee, A. (2012). Social Science Research: Principles, Methods, and Practices. Florida: University of South Florida.

[15] Malebana, J. (2014). Entrepreneurial intentions of South African rural university students: A test of the theory of planned behavior. Journal of Economics and Behavioral Studies.

[16] Creswell, J. W. (2009). Research design: Qualitative, Quantitative, and Mixed Methods Approaches. California: SAGE Publications, Inc.

[17] Marczyk et al., (2005). Essentials of Research Design and Methodology. Hoboken, New Jersey: John Wiley \& Sons, Inc.

[18] Kothari. (2004). Research Methodology, Method and Techniques, 2nd Ed. New Delhi: New Age International (P) Limited, Publishers.

[19] http://methods.sagepub.com/reference/encyclopedia-ofsurvey-research-methods/n503.xml

[20] Sekaran, U. (2003). Research Methods For Business. New York: John Wiley \& Sons, Inc.

[21] http://www.pietutors.com/sample-design/

[22] Talas et al. (2013). The Influence of Demographic Factors on
Entrepreneurial Intention Among Undergraduate Students as a Career Choice: The Case of a Turkish University. American International Journal of Contemporary Research.

[23] Kumar, R. (2011). Research Methodology: A step-by-step guide for beginners, third edition. London: SAGE Publications Ltd.

[24] Lüthje, C. \& Franke, N. (2003). The "making" of an entrepreneur: Testing a model of entrepreneurial intent among engineering students at MIT. R\&D Management, 33 (2), 135147.

[25] Francis et al. (2004). Constructing questionnaires based on the theory of planned behavior: A manual for health services researchers. Newcastle upon Tyne, UK: Centre for Health Services Research, University of Newcastle upon Tyne.

[26] Autio et al. (2001). Entrepreneurial Intent among Students in Scandinavia and in the USA. Enterprise and Innovation Management Studies, 147.

[27] Oyugi, J. (2015). The Mediating Effect of Self-Efficacy on the Relationship Between Entrepreneurship Education and Entrepreneurial Intentions of University Students. Journal of Entrepreneurship Management and Innovation (JEMI), 10.

[28] Pallant, J. (2007). SPSS Survival Manual: A Step by Step Guide to Data Analysis using SPSS for Windows third edition. Sydney: Ligare Book Printer.

[29] Atnafu, A. M. (2016). Analysis on Determinants of Students Self Employment Intension in Newly Established Universities of Ethiopia: The Case of Dire Dawa University. Research on Humanities and Social Sciences.

[30] Morgan. (2004). SPSS for introductory statistics: use and interpretation. New Jersey. London.: Lawrence Erlbaum Associates.

[31] Kolvereid, L. \&. (1997). Entrepreneurship among business graduates: Does a major in entrepreneurship make a difference?. Journal of European Industrial Training.

[32] Akanbi S. (2013). Determinants of entrepreneurial intention. An online journal of the African Educational Research Network.

[33] Van Gelderen et al., (2008). Explaining entrepreneurial intentions by means of the theory of planned behavior. Career Development International.

[34] Bassey, U. and Archibong I. (2005). Assuring quality graduate output through entrepreneurial oriented education in Nigerian universities. Nigerian Journal of Curriculum Studies, 18-23.

[35] Ajzen I. (2005). Attitudes, Personality and Behavior, Second Edition. New York: Open University Press. 